\title{
Chemical Properties
}

National Cancer Institute

\section{Source}

National Cancer Institute. Chemical Properties. NCI Thesaurus. Code C17771.

General term for compositional, structural, and reactivity- affecting qualities of chemical compounds. 